\title{
Factors Influencing Consumers' Willingness to Pay for Nigeria Processed Chicken in Kwara State
}

\author{
A. G. Adeyonu ${ }^{1 *}$, E. O. Oyawoye ${ }^{2}$, E. F. Fabiyi ${ }^{1}$ and A. O. Owolabi ${ }^{1}$ \\ ${ }^{1}$ Department of Agricultural Economics and Extension, Landmark University, Omu-Aran, \\ Kwara State, Nigeria. \\ ${ }^{2}$ Department of Animal Science, Landmark University, Omu-Aran, Kwara State, Nigeria.
}

\begin{abstract}
Authors' contributions
This work was carried out in collaboration between all authors. Author AGA designed the study, wrote the protocol and first draft of the manuscript and managed the analysis. Author EFF took part in the writing of the proposal. All authors read and approved the final manuscript.
\end{abstract}

Article Information

DOI: 10.9734/AJEA/2016/22416

Editor(s):

(1) Rusu Teodor, Department of Technical and Soil Sciences, University of Agricultural Sciences and

Veterinary Medicine Cluj-Napoca, Romania.

Reviewers:

(1) Mevlut Gul, Suleyman Demirel University, Turkey.

(2) Hasan Vural, Uludag University, Turkey.

Complete Peer review History: http://sciencedomain.org/review-history/12373

Original Research Article

Received $30^{\text {th }}$ September 2015

Accepted $31^{\text {st }}$ October 2015

Published 21 ${ }^{\text {st }}$ November 2015

\begin{abstract}
Despite the ban on importation of frozen poultry products in Nigeria, about 1.2 million tonnes unwholesome products are been smuggled into the country annually. This practice is impacting negatively on the health of the citizenry and local producers continue to face daunting obstacles posed by activities of smugglers. This study analyzed the factors influencing urban households' Willingness To Pay (WTP) for Nigeria Processed Chicken (NPC) in Kwara State. Data used for the study were obtained from 274 respondents using the multi-stage sampling techniques. They were analyzed using descriptive statistics and Probit regression. From the study, it is seen that the majority of the respondents (54.7\%) were fairly educated with mean year of schooling of 12.97 . About $34.7 \%$ and $13.9 \%$ of the respondents had below $\mathrm{A} 50,000$ and above $\mathrm{N} 200,000$ respectively as their total monthly income. The result indicates that over $80 \%$ of the respondents claimed that NPC was not readily available while the mean distance to sales outlets stood at $3.21 \mathrm{~km}$. The probit estimation of willingness to pay increased significantly with education and income and decrease with distance to sales outlets. It was recommended that policies that will enhance respondents' purchasing power should be pursued in order to encourage them to pay for Nigeria processed chicken. Also, the creation of more sales outlets for NPC should be considered.
\end{abstract}


Keywords: Nigeria processed chicken; willingness to pay; factors.

\section{INTRODUCTION}

The agricultural sector in Nigeria is the most important non-oil economic activity and it is the single largest employer of labour forces, employing about 70 percent of its workforce [1,2]. It contributed $40.07 \%$ and $22 \%$ (pre and post debasing period respectively) of Gross Domestic Products (GDP) in 2010 and 2014 respectively [3]. The sector consists of crops, fishery, forestry and livestock sub-sectors. The GDP contributed by sub-sectors are; Crops (36.40\%), Fisheries $(1.34 \%)$ Forestry $(0.52 \%)$ and Livestock $(2.61 \%)$. The livestock sub-sector is an important component of the Nigeria agricultural economy. The Nigeria's livestock population consist of 16.3 million Cattle; 40.8 million Goat; 27 million Sheep; 3.7 million Pigs and 151 million poultry [4]. Going by this figure, poultry alone constitutes more than $60 \%$ of the total livestock production, indicating the dominance of poultry sub sector in the livestock industry.

The poultry industry plays important roles in the development of Nigeria economy. The industry provides employment opportunities for the populace, thereby serving as a source of income to the people. Also, it provides a good source of animal protein in terms of meat (chicken) and eggs. Other animal protein sources are: Fish, beef, milk, bacon, pork and mutton [5]. The protein has a high nutritional value [6] as it is important in the building and repair of body tissues; a low intake of protein hinders the development of the brain, reduces the skillfulness of the young, and retards the growth rate and resistance to infections [7]. Chicken consists of high-quality protein, hence, the most widely accepted meat in Nigeria. Unlike beef or pork, it does not have any religious/health taboo. It contributes to a nutritious, balanced diet, which is especially important for children, nursing mothers and people who are ill [8].

Nigeria, with a population of about 170 million [9], is grossly under provided with the essential food component, which is protein. Nigeria's per capita daily protein intake is far below the FAO recommended minimum of $53.8 \mathrm{~g}$. The per capital chicken intake stood at $18.1 \mathrm{~g}$ in 2010 [10]. According to the president of Poultry Association of Nigeria, Nigerian chicken consumption is put at 1.5 million tonnes, while production is estimated to be about 0.35 million tonnes, leaving a demand and supply gap of about 1.2 million tonnes which is met through smuggling. It is worthy of note that a ban was placed on the importation of frozen chicken and turkey in Nigeria in 2000. This was done to protect the local poultry farmers and create jobs. Despite this, the Nigeria market is flooded with smuggled imported frozen poultry products and about $90 \%$ of those imported frozen chickens are unhealthy and contaminated. Surveys have shown that that while locally-produced poultry meats are sold without any preservatives, the smuggled poultry meat is preserved with hazardous chemicals. The formalin load in all smuggled poultry products ranges from 42.9 to $63.3 \mathrm{ml} / \mathrm{kg}$ [11]. This portends serious danger for the consumers as some of the toxic chemicals are known to be carcinogenic. The smuggled frozen poultry products are cheaper than the locally processed one. As at the time of the survey, one $\mathrm{kg}$ of imported frozen poultry products (turkey/chicken) was sold for $\mathbf{A 6 8 0}$ while the price of one $\mathrm{kg}$ of locally processed chicken was about $\mathrm{A750.}$

Owing to the increased interest in improving or maintaining health in a proactive and convenient approach [12], consumers have become more concerned about the nutrition, health, and quality of food they eat [13]. Changing tastes and growing health concerns in Nigeria about smuggled imported poultry have spurred demand for locally dressed chickens. Thus, WTP for NPC can be a good predictor of its demand. To the best of our knowledge, little or nothing is known in the country about the determinants of NPC. Hence, the factors influencing willingness to pay for NPC in Kwara State was investigated thereby contributing to literature on the subject matter in Nigeria.

\subsection{Conceptual Framework}

Willingness to pay for a commodity is the amount of money a person would be willing to pay for higher level of quality. It is a measure of the resources individuals are willing and able to give up (for example) for a reduction in the probability of encountering a hazard that compromises their health [14]. A theoretically correct measure of the value individuals attach to improvements in food safety is their 'WTP' for safer foods [15]. This, therefore, is the largest amount that an individual is willing to pay for a specific improvement in food safety. The notion of willingness to pay could be defined as the sum of money representing the difference between consumers' surplus before and after adding or improving a 
food product attribute [16]. Models that estimate consumers' willingness to pay when adding or enhancing a given quality attributes are based on earlier study by [17] who opines that consumers directly derive utility from the attributes of goods.

Tools for measuring WTP (which include the contingent valuation, travel cost and hedonic pricing) can be used to answer questions such as how much consumers are willing to pay for a quality upgrade or what effect a particular government intervention might be [18]. In this regard, consumers' WTP for NPC can be measured using a direct valuation method such as the Contingent Valuation (CV). The CV method employed in this study affords an accurate analysis of behaviour and motives since its use facilitates changing the information level by applying sub samples [19]. The procedure consists of a dichotomous choice question and a maximum WTP question. In the dichotomous choice question, consumers were asked whether or not they are willing to pay a premium, to buy a NPC instead of an imported smuggled frozen one. The amount is a percentage over the price of the imported one, and differs across consumers. Consumers' responses are 'yes' if they are willing to pay more for a NPC or 'no' otherwise. Consumers were then asked for the exact premium they were willing to pay.

This study was therefore designed to analyse the factors influencing consumers' willingness to pay a premium for NPC in Kwara State.

\subsection{Theoretical Framework}

The subject of choice and willingness to pay are based on the theory of Random Utility. Utility refers to the amount of satisfaction or pleasure that an individual gains from consuming a commodity/product/service. Subjectively, it can be measured by how much the consumer is willing to pay in order to achieve the utility he desires. This theory was pioneered by [20] and is based on the utility maximization theory of consumer preference. The consumer is assumed to be governed by this utility maximization rule, in which he chooses among a selection of goods the one that gives him the highest utility. However, while there are some characteristics that determine the choice a consumer makes, utility in itself is not a totally deterministic variable, thus the term random utility. Any deviation from the consumer actual and predicted choice is assumed to be due to the random error. Examine a consumer faced with a choice between two baskets of goods, $X$ and $Y$, with expected utility of UX and UY. The theory of utility assumes that a rational consumer will choose a basket of good $Y$ if UY $>U X$ and viceversa.

However, utility cannot be predicted exactly as a result of certain attributes of the consumers and the products, as well as the selection situation confronting the consumers. Thus, a random nature in utility is presumed. This assumes that utility, $\mathrm{U}_{\mathrm{ij}}$, derived from a product $\mathrm{j}$ by consumer $\mathrm{i}$ is composed of a deterministic component, $V_{i j}$ and a random/stochastic component $\epsilon_{i j}$, i.e.

$$
U_{i j}=V_{i j}+\varepsilon_{i j}
$$

Consequently, the probability of consumer i, choosing $\mathrm{j}$ from a basket of goods is given as:

$$
\begin{aligned}
& P_{i j}=\operatorname{Pr}\left[U_{i j}>\left\{U_{i j}^{\prime}\right\} \forall_{j} \neq_{j}\right] \\
& P_{i j}=\operatorname{Pr}=\left[V_{i j}+\varepsilon_{i j}>\left\{V_{i j}^{\prime}+\epsilon_{i j}^{\prime}\right\} \forall_{j}^{\prime} \neq j\right]
\end{aligned}
$$

The error terms are the unobserved random variables which may be taken as a joint distribution of all the error terms, i.e $\epsilon_{i}=\left(\epsilon_{i 1}+\epsilon_{i 2}+\epsilon_{i 3}\right)^{T}$. They may be estimated by a cumulative distribution or a probabilistic distribution. The usual model in this estimation is the multinomial logit model. According to [21], in statistics, most unobserved error terms are taken as normally distributed, for which it can be modeled as a probit model, which this study adopted. The $f_{\epsilon}(\epsilon)$ is assumed to be the joint distribution of the error terms, having mean, and a covariance matrix; making it a probit model. The probit model takes the error term to be independently and identically distributed, and thus the probability of making the choice of product "j" can be shown as:

$$
\begin{aligned}
P_{j} & =\operatorname{Pr}\left[\left\{\epsilon_{k}<V_{j}-V_{k}+\varepsilon_{j}\right\} V_{k} \neq j\right] \\
= & \int_{\epsilon_{j}=-\infty}^{\infty} f_{\epsilon j}\left(\epsilon_{j}\right)\left(\prod_{k \neq j}^{V_{k}-V_{j}+\epsilon_{j}}\left(\int_{\epsilon_{k-\infty}}^{\infty} f_{\epsilon k}\left(\epsilon_{k}\right) d \epsilon_{k}\right) d \epsilon_{j}\right. \\
& =\int_{\epsilon_{j=-\infty}}^{\infty} f_{\epsilon j}\left(\epsilon_{j}\right)\left(\prod_{k \neq j} F_{\epsilon j}\left(V_{j}-V_{k}+V_{j}\right)\right) d \epsilon_{j}
\end{aligned}
$$

\section{MATERIALS AND METHODS}

\subsection{The Study Area}

The study was carried out in Kwara State, one of the six states in north central region of Nigeria. The State has sixteen Local Government Areas 
(LGAs) which covers an area of $74,256 \mathrm{sq} \mathrm{km}$ of the total area of Nigeria $(923,768 \mathrm{sq} \mathrm{km}$, approximately one-twelfth) [22]. The State lies between latitude $7{ }^{\circ} 45^{\prime} \mathrm{N}$ and 930 ' $\mathrm{N}$ and longitudes 230 ' $\mathrm{E}$ and $6{ }^{\circ} 5^{\prime} \mathrm{E}$. The annual rainfall pattern across the State extends between the month of April and October with minimum (600$1,500 \mathrm{~mm}$ ) with peak rains in May to June and September to October. The months of November to February are virtually without rainfall and the mean temperatures ranges from $20^{\circ} \mathrm{C}$ to $22^{\circ} \mathrm{C}$. Humidity ranges from $50 \%$ in dry season and up to $85 \%$ in the wet season. The State is bordered in the north by Niger State, in the south by Oyo, Osun and Ekiti States, in the east by Kogi State and in the west by Benin Republic. Because of its unique geographical position, the state is referred to as the "gateway" between the north and the south of the country. Agriculture is the main stay of the economy.

\subsection{Data Source and Sampling Techniques}

A questionnaire survey was undertaken to gather primary data from the respondents. Information gathered from them include their socio-economic characteristics, level of awareness about NPC, availability of NPC, distance to sales outlets, concerns toward health and environment and WTP for NPC among others.

A multistage sampling techniques was used to select the respondents. At the first stage, llorin and Omu-Aran towns were purposely selected. Ilorin was selected because it is the state capital and most populous town in the state. Omu-Aran was selected because it housed Landmark University, a private University with the mandate of revolutionizing agriculture in Africa. In pursuance of the mandate, the University has a chicken processing center. At the second stage, 10 wards were randomly selected from each of the two LGAs in Ilorin and 5 wards in Omu-Aran to make a total of 25 wards. The third and final stage was a random selection of 297 households proportionate to the size of the selected wards. The questionnaire were targeted at the household heads who later nominated one member with adequate information about the subject matter. Only 274 respondents who responded to all questions were selected for the modeling.

\subsection{Analytical Techniques}

Descriptive statistics was used to analyse respondents' socio-economic characteristics while probit regression was used to analyze the factors influencing consumers' willingness to pay for NPC.

\subsubsection{Empirical estimation of the probit model}

The probit model used to estimate the probability of purchasing NPC is given by:

$$
Y_{i}=\mathrm{f}\left(X_{i} \alpha+\varepsilon_{i}\right)
$$

Where:

$$
\begin{aligned}
& Y_{i}=\text { willingness to pay for NPC (with value of } \\
& 1 \text { if willing to pay and } 0 \text { otherwise) } \\
& X_{1}=\text { age of the respondents in years } \\
& X_{2}=\text { sex (male }=1,0 \text { otherwise) } \\
& X_{3}=\text { marital status (married }=1,0 \text { otherwise) } \\
& X_{4}=\text { education in years } \\
& X_{5}=\text { household size in number } \\
& X_{6}=\text { household monthly income in naira } \\
& X_{7}=\text { availability (available }=1,0 \text { otherwise) } \\
& X_{8}=\text { distance to the nearest sales outlet in } \\
& \mathrm{km} \\
& \epsilon_{i}=\text { error term }
\end{aligned}
$$

\section{RESULTS AND DISCUSSION}

\subsection{Socioeconomic Characteristics of Respondents}

Table 1 presents a summary of the socioeconomic characteristics of the respondents in this survey. These are the socioeconomic factors that are expected to apriori have some kind of effect on the willingness to pay for NPC in the study area. As shown in the table, the majority of the respondents were within the age range 30-40 years with average age of 41.42 years. This shows that majority were still in their productive age. Well above three quarter of the respondents were females. This may not be unconnected with the culture in the study area which placed the responsibility of food preparation on the shoulder of females. The majority of the respondents $(90.1 \%)$ were married. About $14 \%$ of the sample had no formal education while the mean years of schooling stood at 12.97 implying that the respondents were moderately educated. About halve of the respondents had between 4-6 members with mean household size of 5 . The recommended household size in the country is 4 members [23]. Sadly, the monthly income of the majority of the respondents (34.7\%) was below $\$ 50,000$, while those with income of above $\$ 200,000$ were just about $15 \%$ with mean monthly income of 
A113,083.9. About $80 \%$ of the sample reported that NPC was not readily available, while more than halve of them had to travel for more than 3 $\mathrm{km}$ to buy NPC with mean distance of $3.21 \mathrm{~km}$. The meaning is that sales outlets for NPC are far away from the dwellings of the consumers. This will, however, influence the decision of the consumers to purchase NPC even if it is not as expensive as the imported frozen chicken.

Table 1. Socioeconomic characteristics of respondents in the study area

\begin{tabular}{|c|c|c|}
\hline Variables & Frequency & Percent \\
\hline \multicolumn{3}{|l|}{ Age (years) } \\
\hline$<30$ & 30 & 10.9 \\
\hline $30-40$ & 120 & 43.8 \\
\hline $41-50$ & 91 & 33.2 \\
\hline$>50$ & 55 & 20.1 \\
\hline Mean & 41.42 & \\
\hline Standard deviation & 10.34 & \\
\hline \multicolumn{3}{|l|}{ Sex } \\
\hline Male & 60 & 21.9 \\
\hline Female & 214 & 78.1 \\
\hline \multicolumn{3}{|l|}{ Marital status } \\
\hline Married & 247 & 90.1 \\
\hline Single & 27 & 9.9 \\
\hline \multicolumn{3}{|l|}{ Years of schooling } \\
\hline 0 & 39 & 14.2 \\
\hline 6 & 59 & 21.5 \\
\hline 12 & 96 & 35.1 \\
\hline$>12$ & 80 & 29.2 \\
\hline Mean & 12.97 & \\
\hline Standard deviation & 4.23 & \\
\hline \multicolumn{3}{|l|}{ Household size } \\
\hline $1-3$ & 80 & 29.2 \\
\hline $4-6$ & 153 & 55.8 \\
\hline $7-9$ & 32 & 8.0 \\
\hline$>9$ & 9 & 3.3 \\
\hline Mean & 5.0 & \\
\hline Standard deviation & 2.92 & \\
\hline \multicolumn{3}{|l|}{ Income (A) } \\
\hline$<50,000$ & 95 & 34.7 \\
\hline $50,000-100000$ & 91 & 33.2 \\
\hline $100,001-150,000$ & 35 & 12.8 \\
\hline $150,001-200,000$ & 39 & 14.2 \\
\hline$>200,000$ & 38 & 13.9 \\
\hline Mean & $113,083.9$ & \\
\hline Standard deviation & $107,515.6$ & \\
\hline \multicolumn{3}{|l|}{ Availability } \\
\hline Available & 47 & 17.2 \\
\hline Not available & 227 & 82.8 \\
\hline \multicolumn{3}{|c|}{ Distance to the nearest sales outlet $(\mathrm{km})$} \\
\hline$<1$ & 36 & \\
\hline $1-3$ & 88 & \\
\hline$>3$ & 150 & 13.1 \\
\hline Mean & 3.21 & 32.1 \\
\hline Standard deviation & 0.96 & 54.7 \\
\hline
\end{tabular}

Table 2. Probit regression of the factors influencing willingness to pay for Nigeria processed chicken

\begin{tabular}{|c|c|c|c|c|}
\hline Variables & Parameters & Std error & $\mathbf{z}$ & $P>|z|$ \\
\hline Age & -0.157 & 0.133 & -1.18 & 0.239 \\
\hline Sex & -2.703 & 1.950 & 1.39 & 0.166 \\
\hline $\begin{array}{l}\text { Marital } \\
\text { status }\end{array}$ & -0.377 & 0.256 & -1.48 & 0.140 \\
\hline Education & $0.803^{* *}$ & 0.322 & 2.49 & 0.013 \\
\hline $\begin{array}{l}\text { Household } \\
\text { size }\end{array}$ & -0.001 & 0.238 & -0.01 & 0.996 \\
\hline Income & $0.001^{*}$ & 0.001 & 1.67 & 0.095 \\
\hline $\begin{array}{l}\text { Distance } \\
\text { to sales } \\
\text { outlets }\end{array}$ & $-1.086^{\star \star *}$ & 0.312 & -3.48 & 0.001 \\
\hline Constant & -2.724 & 4.379 & -0.62 & 0.534 \\
\hline Log & -0.241 & & & \\
\hline likelihood & 0.681 & & & \\
\hline Pseudo R & 0.002 & & & \\
\hline $\begin{array}{l}\text { squared } \\
\text { Prob > } \\
\text { chi2 }\end{array}$ & & & & \\
\hline
\end{tabular}

\subsection{Factors Influencing Willingness to Pay for NPC}

Table 2 above shows the results of probit regression. The model produced a good fit of the data with the Chi square value of the regression being statistically significant $(P<0.01)$ while the Pseudo $\mathrm{R}$ squared indicates that about $68 \%$ of the variations in the dependent variable (WTP) is explained by the independent variables. Thus, from the diagnostic tests, it show that the model fits the data properly. Three of the variables have significant coefficients at various levels of significance and all have expected signs. The years of schooling and WTP for NPC are positively related. This shows that willingness to pay increases with increase in level of education. This is expected because the educated ones are more enlightened about the health benefits as well as positive impact on the local economy compared with the consumption of imported frozen chicken [24]. Also, average monthly mean income and WTP are directly related. An increase in the consumer's income is expected to increase his willingness to pay for NPC since he is now able to afford the little bit expensive NPC compared with the smuggled imported frozen chicken. The findings is in line with those [25] who reported that willingness to pay for healthy food and respondents socio-economic characteristics are positively related. The results further reveal that distance to NPC sales outlets and WTP are negatively linked. 


\section{CONCLUSION AND RECOMMENDA- TIONS}

This study utilized primary data collected from respondents to examine the factors influencing households' willingness to pay for Nigeria processed chicken. It was found that education and income directly influenced households' willingness to pay for Nigeria processed chicken, while distance to sales outlets indirectly influenced it. Arising from the foregoing, it is recommended that policies that will enhance respondents' purchasing power should be pursued in order to encourage their willingness to pay for Nigeria processed chicken. Also, to ensure that more Nigerians patronize Nigeria processed chicken, there is the need for more sales outlets in the study area. This can be addressed by collaborating with standard supermarkets in urban centres to serve as sales outlets. Improvement in electricity situation in the area is also recommended. This will not only help in safeguarding the health of Nigerians but also contribute to reduction in high rate of unemployment in the country, since increased demand for NPC will stimulate local poultry production.

\section{COMPETING INTERESTS}

Authors have declared that no competing interests exist.

\section{REFERENCES}

1. National Bureau of Statistics (NBS). Social Statistics in Nigeria. Abuja; 2009.

2. United States Department of Agriculture (USDA), International Egg and Poultry Review. 2013;16:8-13.

3. National Bureau of Statistics (NBS). Social Statistics in Nigeria. Abuja; 2014.

4. Lombin L. National Veterinary Research Institute, Jos. Annual National Conferences paper presented at Abuja. $2011 ; 20$.

5. Apantaku SO. Analysis of participation of farmers in participatory poultry production research in Lagos State, Nigeria. Livestock Research for Rural Development. 2006; 18:7.

Available:http://www.Irrd.org//rrd18/7/ pan18094htm

(7 April 2015)

6. Abedullah A, Maqbool A, Bukhsh K. Issues and economics of poultry production: A case study of Faisalabad, Pakistan. Pakistan Veterinary Journal. 2003;27:2528.

7. Ogidan IO. Economic appraisal of livestock feed industry in Osun State. B. Agric. Thesis, Department of Agricultural Economics, Obafemi Awolowo University lle-Ife. 2002;40.

8. Australian Centre for International Agricultural Research (ACIAR). Improving village chicken production: A manual field workers and trainers, The Monograph series. 2009;31.

9. National Bureau of Statistics (NBS). Social Statistics in Nigeria. Abuja; 2012.

10. FAOSTAT. Searchable online database from Food and Agriculture Division of the United Nations. Rome, Italy; 2012.

Available:http://faostat.fao.org/site/567/Des ktopDefault.aspx?PagelD=567\#ancor/

(Retrieved 20 June 2015)

11. Falaju J. Effects of imported poultry products on health, economy. The Guardian; 2015.

12. De Jong $\mathrm{N}$, Ocké $\mathrm{MC}$, Branderhorst $\mathrm{H}$, Friele R. Demographic and lifestyle characteristics of functional food consumers and dietary supplement users. British Journal of Nutrition. 2003;89:273281.

13. Gill JM, Gracia A, Sanchez M. Market segmentation and willingness to pay for organic products in Spain. International Food and Agribusiness Management Review. 2000;3:207-226.

14. Golan E, Kuckler F. Willingness to pay for food safety: Costs and benefits of accurate measures. American Journal of Agricultural Economics. 1999;81:11851991.

15. Spencer $\mathrm{H}$. Consumer willingness to pay for reduction in the risk of food poisoning in UK. Journal of Agricultural Economics. 1996;47:403-420.

16. Gil JM, Gracia A, Sanchez M. Market segmentation and willingness to pay for organic products in Spain. International Food and Agribusiness Management Review. 2000;3:207-226.

17. Lancaster KJ. A new approach to consumer theory. Journal of Political Economy.1996;74:132-157.

18. James JS. Research project outline on consumer valuation of food quality attributes. Office of the Dean, College of Agricultural Sciences. The Pennsylvania State University; 2002. 
19. Verbic M, Slabe - Ekeer R. An economic analysis of willingness to pay for sustainable development: A case study of the Voliji Pitok landscape area. Ecological Economics. 2009;68:1316-1328.

20. McFadden D. Econometric models for probabilistic choice among Products. The Journal of Business. 1980;53:13-29.

21. Train K. Discrete choice methods with simulation. Cambridge University Press; 2003.

22. National Population Commission (NPC). National Bureau of Statistics Official Gazatte; 2006.
(FGP 71/52007/2,500(OL24). Abuja. Available:http://www.nigerianstat.gov.ng. (Retrieved on 2015-04-30)

23. Alabi RA, Haruna MB. Technical efficiency of family poultry production in Niger-Delta. Journal of Central European Agriculture. 2005;6:531-538.

24. Falaju J. Effects of imported poultry products on health, economy. The Guardian; 2015.

25. Childs NM, Poryzees GH. Foods that help prevent disease: Consumer attitudes and public policy implications. Journal of Consumer Marketing. 1997;14:433-447.

(0) 2016 Adeyonu et al.; This is an Open Access article distributed under the terms of the Creative Commons Attribution License (http://creativecommons.org/licenses/by/4.0), which permits unrestricted use, distribution, and reproduction in any medium, provided the original work is properly cited.

Peer-review history:

The peer review history for this paper can be accessed here: http://sciencedomain.org/review-history/12373 